\title{
Vaginal Cuff Dehiscence after Hysterectomy and One Minute Technique of Laparoscopic Vault Closure
}

Karki GMS ${ }^{1}$, Neupane BB ${ }^{1}$, Regmi MC ${ }^{2}$, Shrestha $\mathrm{R}^{2}$, Gupta $\mathrm{SN}^{2}$

${ }^{1}$ Department of Obstetrics and Gynaecology, Birat Medical College, Biratnagar, Nepal, ${ }^{2}$ Department of Obstetrics and Gynaecology, B. P. Koirala Institute Health Sciences, Dharan, Nepal.

Received: 23-Jan-2016; Accepted: 24-Jun-2016

\begin{abstract}
Aims: This study was done to observe the rate of vaginal cuff dehiscence of one minute technique of laparoscopic vault closure in laparoscopic hysterectomy.

Methods: It was a descriptive study performed in Birat Hospital among 1012 patients undergoing total laparoscopic hysterectomy for both benign and malignant gynaecological conditions between 2012 to 2013 . Monopolar cautery was used for laparoscopic colpotomy and vault was closed by laparoscopic single running suture, that is, one-minute laparoscopic vault closure technique. Patients were followed up for vaginal cuff dehiscence and the dehiscence rate was compared with other techniques of laparoscopic vault closure in laparoscopic hysterectomy.
\end{abstract}

Results: This study showed that the rate of vaginal cuff dehiscence after one minute technique of laparoscopic vault closure in laparoscopic hysterectomy was $1 / 1012$ patients $(0.09 \%)$ which was significantly less as compared to other techniques of laparoscopic vault closure in laparoscopic hysterectomy quoted in the literature.

Conclusions: One minute technique of laparoscopic vault closure after colpotomy with monopolar cautery using single running suture has encouraging results. It is a noble technique of laparoscopic vault closure with excellent support. It can be practiced in low resource setting also.

Keywords: colpotomy, cuff dehiscence, hysterectomy, monopolar cautery, vault closure.

\section{INTRODUCTION}

Vaginal cuff dehiscence (VCD) has been defined as a full thickness separation, partial or total, of the anterior and posterior edges of the vaginal cuff with or without bowel evisceration. ${ }^{1}$ After laparoscopic removal of the uterine specimen, the vaginal cuff is closed by different laparoscopic techniques. The term vaginal cuff dehiscence is frequently interchanged with terms cuff separation or cuff rupture. ${ }^{2}$ VCD had complicated gynecologic surgery long before the advent of laparoscopic approach to hysterectomy. ${ }^{3}$ Several authors have reported different surgical approaches such as abdominal, vaginal and laparoscopic, without substantial differences on incidence of VCD. ${ }^{4-10}$

Vaginal evisceration after hysterectomy, although rare, is a severe post-operative complication for both

\section{CORRESPONDENCE}

Dr. Gyanendra Man Singh Karki

Department of Obstetrics and Gynaecolgy

Birat Medical College, Biratnagar, Nepal

Email: gkarms09@gmail.com

Phone: +977-9851136460 young and elderly patients and is associated with bowel evisceration. ${ }^{11}$ In premenopousal patients, sexual intercourse before healing of the vaginal cuff or associated with cuff infections or hematomas, is the main trigger event. ${ }^{12,13}$ The scar tissue attains about $40 \%$ of its final strength in the first month and the strength continues to increase for as long as a year after injury. ${ }^{14}$ In postmenopousal patients, the evisceration is always considered a spontaneous event. It happened quite late, with a mean onset of 36.8 months after surgery. The atrophic vagina coincided with the triad of hypoestrogenism, chronic tissue devascularization, and pelvic floor weaknesses and association with a sudden increase in abdominal pressure (vomiting, coughing, sneezing, and straining at toilet, heavy weight lifting) has to be considered. ${ }^{12,13,15}$

It is reported that the incidence of VCD $(0.3-3.1 \%)$ after total laparoscopic hysterectomy (TLH) is higher compared with the abdominal $(0.15-0.26 \%)$ and vaginal (0.08-0.25\%) approach. ${ }^{3}$ Among laparoscopic hysterectomies, those with vaginal closure of the cuff have a lower incidence of dehiscence (0.18-0.30\%) than laparoscopic closure $(0.64 \%){ }^{16,17}$ 
This study was conducted in Birat hospital to see the rate of vault dehiscence after laparoscopic vault closure with one minute technique in laparoscopic hysterectomy.

\section{METHODS}

It was a descrriptive study performed over two years from 2012-2013 in Birat Hospital, Biratnagar. The study protocol was approved by the Institutional Ethical Committee of the hospital. A total of 1012 patients of age group of 40-49 years and body mass index of $20-25 \mathrm{~kg} / \mathrm{m}^{2}$ who had benign or malignant gynaecological conditions like symptomatic uterine fibroids, endometriosis, adenomyosis, premalignant lesions of cervix, endometrial carcinoma and abnormal uterine bleeding unresponsive to medical management. and completed the family were included in the study. Written informed consent was taken from the patients before the enrollment. Those who had medical and surgical illness like uncontrolled hypertension, diabetes, bleeding disorders etc. were excluded from the study. All baseline preoperative investigations like complete blood count, blood group, urea, creatinine, prothrombin time, random blood sugar, chest x-ray, urine routine microscopy and electrocardiogram were done and blood was arranged before planning for TLH. In this study, all patients underwent monopolar colpotomy during hysterectomy and laparoscopic vault closure with single running suture, that is, one minute technique of laparoscopic vault closure. This noble technique was started with suturing from one angle of the vault preferably from left uterosacral ligament along with posterior vaginal wall then anterior vaginal wall then middle of the posterior vaginal wall then anterior wall then again left uterosacral ligament along with posterior vaginal wall with anterior vaginal wall in continued fashion. The sutures were tied in middle.

The patients were followed up for vaginal cuff dehiscence after discharge from the hospital with the telephonic enquiry at three months. Furthermore, the route of vaginal vault closure, type of electrocautery used during surgery, method of suturing and different risk factors like age, BMI, length of surgery, intraoperative blood loss, onset of VCD after surgery and post coital evisceration were also discussed in the study. The data were recorded in SPSS version 13 and analyzed.

\section{RESULTS}

There were 1012 patients who had undergone TLH in the study out of which only one $(0.09 \%)$ had vault dehiscence.

Table 1. Baseline characteristics $(n=1012)$.

\begin{tabular}{|ll|}
\hline Characters & Value \\
\hline Mean age (years) & $44.9 \pm 6.3(40-49)$ \\
\hline Mean BMI (kilogram/metre ${ }^{2}$ ) & $22 \pm 2.1(20-25)$ \\
\hline Mean parity & $2.3 \pm 2.5$ \\
Mean operative time (minutes) & $65 \pm 14.5$ \\
Mean blood loss (millilitres) & $90 \pm 21$ \\
Mean hospital stay (days) & $5 \pm 3.1$ \\
\hline Indication: benign & 1003 \\
Indication: malignant & 9 \\
\hline
\end{tabular}

The mean age of the patients who had surgery was 44.9 years, the mean operative time was 65 minutes, mean blood loss was 90 millilitres and mean hospital stay was five days. One thousand and three $(99.1 \%)$ patients were operated for benign gynecological conditions and the most common indication was symptomatic uterine leiomyoma $(\mathrm{n}=772,76.96 \%)$. Nine $(0.9 \%)$ patients were operated for malignancy and carcinoma endometrium was most common malignant condition $(n=6,66.66 \%)$ [Table-1].

Table 2. Post operative complications ( $n=79)$.

\begin{tabular}{|ll|}
\hline Complications & Number(\%) \\
\hline Pain and spotting & $45(4.44 \%)$ \\
Primary haemorrhage & $21(2.07 \%)$ \\
Vault infection & $12(1.01 \%)$ \\
Vault dehiscence & $1(0.09 \%)$ \\
\hline
\end{tabular}

Seventy nine $(7.8 \%)$ patients had post operative complications and the most common complication was pain and spotting in postoperative period $(n=45$, $4.44 \%$ ) which was managed conservatively. Vault dehiscence was seen in only one $(0.09 \%)$ patient operated for a benign gynaecological condition and dehiscence was seen on $20^{\text {th }}$ postoperative day. There was history of early onset of sexual intercourse in the same patient which was seen as a risk factor for vault dehiscence [Table-2].

\section{DISCUSSION}

The incidence of VCD in this study was one out of 1012 , which reflects $0.09 \%$ and it is significantly lower compared to the studies done by Blikkendaal et $\mathrm{al}^{19}(1.2 \%)$, Uccella et $\mathrm{a}^{16}(0.64 \%)$, Ceccaroni et $\mathrm{al}^{18}(0.8 \%)$ and Laco PD et al ${ }^{9}(0.79 \%)$ but consistent with the study done by Singh K et al ${ }^{10}(0 \%)$ [Table-3]. 
Karki et al. Vaginal Cuff Dehiscence.

Table 3. Comparision of baseline characteristics, risk factors, colpotomy technique and route of vault closure

\begin{tabular}{|c|c|c|c|c|c|}
\hline & $\begin{array}{l}\text { Birat } \\
\text { Hospital }\end{array}$ & Blikkendaal et al19 & Uccella et al16 & $\begin{array}{l}\text { Ceccaroni et } \\
\text { al18 }\end{array}$ & $\begin{array}{l}\text { Singh K et } \\
\text { al10 }\end{array}$ \\
\hline TLH & 1012 & 331 & 3573 & 2745 & 35 \\
\hline Mean age (years) & 44.9 & 49 & 50.5 & 46.4 & 41.9 \\
\hline BMI & 22 & 27.5 & & 23 & \\
\hline $\begin{array}{l}\text { Intraoperative blood loss } \\
\text { (millilitres) }\end{array}$ & 50 & 120 & & 109.3 & \\
\hline Indication: benign & $1 / 1003$ & & $17 / 3125$ & & \\
\hline Indication: malignant & $0 / 9$ & & $6 / 448$ & & \\
\hline Onset of dehiscence (days) & 20 & & 30 & 90 & \\
\hline Route of vault closure & $\begin{array}{l}\text { all } \\
\text { laparoscopic } \\
\text { running } \\
\text { closure }\end{array}$ & $\begin{array}{l}\text { Transvaginal } \\
=75 ; \text { laparoscopic } \\
\text { interrupted }=90 ; \\
\text { laparoscopic } \\
\text { running=166 }\end{array}$ & $\begin{array}{l}\text { transvaginal } \\
=1241 ; \\
\text { laparoscopic } \\
\text { interrupted } \\
=2332\end{array}$ & $\begin{array}{l}\text { laparoscopic } \\
\text { interrupted = } \\
2745\end{array}$ & $\begin{array}{l}\text { all } \\
\text { laparoscopic } \\
\text { running } \\
\text { closure }\end{array}$ \\
\hline VCD & $\begin{array}{l}1 \mathrm{VCD}- \\
\text { laparoscopic } \\
\text { running }\end{array}$ & $\begin{array}{l}1 \text { VCD-transvaginal } \\
\text { interrupted; } \\
3 \text { VCD-laparoscopic } \\
\text { interrupted }\end{array}$ & $\begin{array}{l}3 \text { VCD- } \\
\text { transvaginal } \\
\text { interrupted; } \\
20 \text { VCD- } \\
\text { laparoscopic } \\
\text { interrupted }\end{array}$ & $\begin{array}{l}22 \mathrm{VCD}- \\
\text { laparoscopic } \\
\text { interrupted }\end{array}$ & $0 \mathrm{VCD}$ \\
\hline
\end{tabular}

In this study, all patients $(\mathrm{n}=1012)$ underwent monopolar colpotomy similar to the studies done by Uccella et $\mathrm{al}^{16}(\mathrm{n}=3573)$, Ceccaroni et $\mathrm{al}^{18}(\mathrm{n}=2745)$ and Singh $\mathrm{K}_{\text {et }} \mathrm{al}^{10}(\mathrm{n}=35)$ but in contrast, Blikkendaal et $\mathrm{al}^{19}(\mathrm{n}=331)$ in their study had used bipolar and ultrasonic electrocautery source for colpotomy. There were less VCD reported with monopolar electrocautery used for colpotomy as seen in this study and similar studies done by Uccella et $\mathrm{al}^{16}$, Ceccaroni et $\mathrm{al}^{18}$ and Singh $\mathrm{k}$ et $\mathrm{al}^{10}$ compared to bipolar electrocautery seen in the study by Blikkendaal et $\mathrm{al}^{19}$. Consistent to this result, Blikkendaal et $\mathrm{al}^{19}$ in their study hypothesised that the type and amount of coagulation used for colpotomy may play a role in the increased risk of VCD after TLH.

In this study, all patients had undergone laparoscopic vault closure with single running suture (one minute technique of vault closure) similar to Singh $\mathrm{K}$ et $\mathrm{al}^{10}$ but in contrast, studies done by Blikkendaal et $\mathrm{al}^{19}$ had used transvaginal $(\mathrm{n}=75)$, laparoscopic interrupted $(n=90)$ and laparoscopic running $(n=166)$ technique; Uccella et $\mathrm{al}^{16}$ had used transvaginal $(n=1241)$ and laparoscopic interrupted $(n=2332)$ technique and Ceccaroni et $\mathrm{al}^{18}$ had used laparoscopic interrupted $(n=2745)$ techniques of vault closure. The rate of VCD in patients with vault closure by laparoscopic single running suture was only one out of $1012(0.09 \%)$ in this study and none in the studies done by Singh et $\mathrm{al}^{10}(\mathrm{n}=35)$ and Blikkendaal et al ${ }^{19}$ $(n=166)$ which was significantly less compared to vault closure by transvaginal route seen in the studies by Uccella et $\mathrm{al}^{16}(3 / 1241=0.24 \%)$ and Blikkendaal et $\mathrm{al}^{19}(1 / 75=1.33 \%)$. The rate of VCD was even more with vault closure by laparoscopic interrupted technique seen in the studies by Uccella et $\mathrm{al}^{16}$ $(20 / 2332=0.85 \%)$, Blikkendaal et $\mathrm{al}^{19}(3 / 90=3.33 \%)$ and Ceccaroni et $\mathrm{al}^{18}(22 / 2745=0.8 \%)$. The pooled incidence of VCD was lower for vault closure by transvaginal $(0.13 \%)$ than for laparoscopic cuff closure $\quad(0.73 \%) \quad[\mathrm{OR}=0.18 ; 95 \% \quad \mathrm{CI}=0.07-0.43]$. Uccella et $\mathrm{al}^{16}$ in their study strongly supported that transvaginal suturing appeared to reduce the risk of vaginal dehiscence over laparoscopic cuff closure after total laparoscopic hysterectomy. Similarly, Blikkendaal et $\mathrm{al}^{19}$ also observed that besides the type and amount of coagulation used for colpotomy, the route and type of vault closure also played the role in the rate of VCD.

Regarding the risk factors and basic demographic variables, the mean age (44.9 years) and body mass index $\left(22 \mathrm{~kg} / \mathrm{m}^{2}\right)$ of the patients operated in this study were similar in characteristics to the studies 
done by Blikkendaal et $\mathrm{al}^{19}$ (49 years, $27.5 \mathrm{~kg} /$ $\mathrm{m}^{2}$ ), Uccella et $\mathrm{al}^{16}$ (50.5 years), Ceccaroni et a $\mathrm{l}^{18}$ (46.4 years, $23 \mathrm{~kg} / \mathrm{m}^{2}$ ) and Singh $\mathrm{K}$ et $\mathrm{al}^{10}(41.9$ years). But, the mean intraoperative blood loss (50 millilitres) and mean length of surgery (55 minutes) in this study were significantly less compared to the studies by Blikkendaal et al ${ }^{19}$ (120 millilitres, 129 minutes), Ceccaroni et a $1^{18}$ (109.3 millilitres, 101.3 minutes) and Singh k et al ${ }^{10}$ (77 minutes). Ceccaroni et $\mathrm{al}^{18}$ concluded that VCD is a spontaneous event in elderly while early sexual intercourse before the complete healing is the triggering risk factor for VCD (7/22) in young patients and occurred on an average of 70th postoperative day. In this study, the only
VCD was seen after the history of early resumption of intercourse and on $20^{\text {th }}$ postoperative day which was significantly less and on the earlier day compared to the study by Ceccaroni et a $1^{18}$ but consistent with the study by Uccella et $a{ }^{16}$ in which early intercourse before complete healing was the accountable event for one $\operatorname{VCD}(1 / 23)$ and on 30th postoperative day.

\section{CONCLUSIONS}

One minute technique of laparoscopic vault closure using monopolar electrocautery for colpotomy and laparoscopic single running suture for vault closure has excellent result in supporting the vault with significantly less incidence of VCD. This can be practiced in low resourced setting as well.

\section{REFERENCES}

1. Kho RM, Akl MN, Cornella JL, Magtibay PM, Wechter ME, Magrina JF. Incidence and characteristics of patients with vaginal cuff dehiscence after robotic procedures. Obstet Gynecol. 2009;114:231-5.

2. Hye-chun H. Vaginal cuff dehiscence after hysterectomy. UpToDate 2015.

3. Raquel M, Tania F. Vaginal cuff dehiscence after minimal invasive hysterectomy: Laparoscopic surgical techniques. World J Laparosc Surg. 2013;6(2):81-85.

4. Hur HC. Vaginal cuff dehiscence after hysterectomy. UpToDate 2012 Oct. Available at: http://www.uptodate.com. Accessed November, 2012.

5. Somkuti SG, Vieta PA, Daugherty JF, Hartley LW, Blackmon EB. Transvaginal evisceration after hysterectomy in premenopausal women: a presentation of three cases. Am J Obstet Gynecol. 1994;171:567-8.

6. De Lancey JO, Starr RA, Elkins TE. Incisional hernia of the vaginal apex following vaginal hysterectomy in a premenopausal, sexually inactive woman. Obstet Gynecol. 1989;73:880-1.

7. Croak AJ, Gebhart JB, Klingele CJ, Schroeder G, Lee RA, Podratz KC. Characteristics of patients with vaginal rupture and evisceration. Obstet Gynecol. 2004;103:572-6.

8. Kowalski LD, Seski JC, Timmins PF, Kanbour AI, Kunschner AJ, Kanbour-Shakir A. Vaginal evisceration: presentation and management in postmenopausal women. J Am Coll Surg. 1996;183:225-9.

9. Laco PD, Ceccaroni M, Alboni C. Transvaginal evisceration after hysterec- tomy: Is vaginal cuff closure associated with a reduced risk? Eur J Obstet Gynecol Reprod Biol. $2006 ; 125: 134-8$.

10. Singh K, Shah B, Patel V, Goswami M, Shah MB. Vaginal vault closure techniques in total laparoscopic hysterectomy: a comparison between laparoscopic route vault suturing and vaginal route suturing. National Journal of Community Medicine. 2011;2(3):289.

11. Ferri J, Simon C, Ruiz G. Vaginal evisceration: surgical repair with synthetic mesh. Int J Gynecol Obstet. 1996;54:183-4.

12. Cardosi RJ, Hoffman MS, Roberts WS, Spellacy WN. Vaginal evisceration after hysterectomy in premenopausal women. Obstet Gynecol.1999;94:859.

13. Kambouris AA, Drukker BH, Barron J. Vaginal evisceration. Arch Surg. 1981;116:949-51.

14. Kirsner RS, Edglstein WH. The wound healing process. Dermatol Clin. 1993;11:629-40.

15. Van Dam JH, Gosselink MJ, Drogendijk AC, Hop WCJ, Schouten WR. Changes in bowel function after hysterectomy. Dis Colon Rectum. 1997;40:1342-7.

16. Uccella S, Ghezzi F, Mariani A. Vaginal cuff closure after minimally invasive hysterectomy:our experience and systematic review of the literature. Am J Obstet Gynecol. 2011;205:119.

17. Cronin B, Sung VW, Matteson KA. Vaginal cuff dehiscence: risk factors and management. Am J Obstet Gynaecol. 2012;206(4):284-288.

18. Ceccaroni M, Uccella S, Cromi A. Vaginal cuff dehiscence in a series of 12,398 hysterectomies: effect of different types of colpotomy and vaginal closure. Obstet Gynecol. 2012;120:516.

19. Blikkendaal MD, Twijnstra ARH, Pacquee SCL, Rhemrev JPT, Smeets MJ GH, Kroon CD, Jansen FW. Vaginal cuff dehiscence in laparoscopic hysterectomy: influence of various suturing methods of the vaginal vault. Gynecol Surg. 2012;9:393-400. 